\title{
The Decreasing Role of the USA in Promoting Human Rights
}

\section{Susan Mapp ${ }^{1} \cdot$ Shirley Gatenio Gabel ${ }^{2}$}

Published online: 16 May 2019

(C) Springer Nature Switzerland AG 2019

In the years following the end of the Second World War, the USA used its status as a world power to promote the idea of universal human rights. A committee led by Eleanor Roosevelt, the widow of the US president and a formidable proponent of human rights, developed the Universal Declaration of Human Rights, the most translated document in the world. This document established the bold idea that there was a minimum level of human rights to which all people everywhere were entitled, regardless of what country in which they lived, what identity they held, or any other category of difference.

However, since that time, the USA has been a reluctant partner in the idea of global human rights and holding itself to those standards; it has ratified only one of the Covenants that established the UDHR in international law, and only two of the Conventions - the Convention on the Elimination of All Forms of Racial Discrimination and the Convention against Torture. It is the only country in the world not to have ratified the Convention on the Rights of the Child. Despite this reticence to apply these global human rights norms to itself, each year, the USA releases an assessment of how well other countries perform in this area.

This stance has become substantially worse since the Trump Administration came to power in 2017. The USA withdrew from the Human Rights Council at the UN in 2018, just days before the Council released its report from the Special Rapporteur on Extreme Poverty and Human Rights, which was extremely critical of the United States' track record on poverty and particularly noted how the policies of the Trump Administration worsened an already bad situation by seeking to slash the social safety net and

Susan Mapp

mapps@etown.edu

Shirley Gatenio Gabel

gateniogabe@fordham.edu

1 Elizabethtown College, Elizabethtown, PA, USA

2 Fordham University, New York, NY, USA provide more to the wealthy. In recent months, the Trump Administration has denied visas to human rights investigators seeking to assess the situation of migrants, especially intended asylum seekers, on the southern border, as well as to members of the International Criminal Court seeking to investigate possible war crimes committed by the United States in Afghanistan. In the Spring of 2019, the USA forced a re-wording of a United Nations resolution on the use of rape as a weapon of war to eliminate language on reproductive and sexual health. It is also not supporting the Conventions it has ratified. It is currently more than a year and a half late on submitting its periodic review to the Committee on the Elimination of Racial Discrimination and recently declined to appoint a member to that body, despite an increasing number of hate crimes occurring since the 2016 election.

While this journal has an international focus and prides itself on publishing authors from around the world, it is based in the USA, and it is essential that social workers in this country work to help all peoples achieve their human rights. However, this is limited by the decision of the US National Association of Social Workers not to include a specific reference to human rights when updating its Code of Ethics, despite the fact that many other countries do and that the International Federation of Social Workers includes human rights in its definition of social work (Mapp et al. in press). US social work education still prioritizes the concept of social justice over that of human rights, and students are limited in their understanding of international documents and norms (Gatenio Gabel and Mapp in press).

The articles in this issue add much-needed information to this discussion of how to further human rights, in the USA and beyond. Howell examines the issue of the removal of the right to vote in the USA from substance users convicted of related crimes, while Rossiter and McPherson explore what a rights-based approach to social work in the jails might look like. Bokek-Cohen as well as Gerlach offer opportunities to learn from cultural traditions in other countries. Borek-Cohen analyzes the consequences of matchmaking practices in certain communities 
in Israel while Gerlach provides us with insight into the concept of buen vivir from indigenous communities in Latin American countries. Rotabi et al. discuss how to apply the rights-based approach in developing effective child protection systems in India, while Fronek et al. discuss how to further children's rights through alternative care policies in Cambodia. All of these authors offer important information to help chart a path to the future based on human rights. Social workers should be at the forefront of bringing about the realization of rights.

\section{References}

Gatenio Gabel, S., \& Mapp, S. C. (in press). Teaching human rights and social justice in social work education. Journal of Social Work Education.

Mapp, S. C., McPherson, J., Androff, D., \& Gatenio Gabel, S. (in press). Social work is a human rights profession. Social Work.

Publisher's Note Springer Nature remains neutral with regard to jurisdictional claims in published maps and institutional affiliations. 